\title{
Pääluottamusmies Aliisan tarina
}

\begin{abstract}
픈
Liiketoiminnan ehtojen radikaali muuttuminen tuo mukanaan

monimutkaisia ongelmia teollisuustyöhön. Tarina osoittaa, kuinka pääluottamusmies Aliisa kasvaa yhteiskunnalliseksi toimijaksi ja vaikuttajaksi ristiriitaisten odotusten paineessa.
\end{abstract}

TÄMÄ ARTIKKELI käsittelee pääluottamusmies Aliisan toimintaa, ajatuksia ja perusteluja omalle toiminnalleen. Tarina pohjautuu usean vuoden aikana tapahtuneisiin keskusteluihin Aliisan kanssa. Tapahtumat liittyvät ajankohtaan, jolloin tekstiili- ja vaatetusteollisuus oli läpikäymässä syvällistä muutosvaihetta, jotta se kykenisi sopeutumaan alalla vallitsevaan maailmanlaajuiseen kilpailuun ja työnjakoon. Tarinan tavoitteena on valottaa Aliisan toimijuutta teollisen kriisin keskellä kohdentaen huomion erityisesti siihen, mitä resursseja yksilölliselle ja kollektiiviselle toimijuudelle niissä olosuhteissa oli tarjolla ja millaiset asiat ja seikat asettivat rajoja toimijuudelle.

Tapahtuma-ajankohtaa voi kuvata murrosvaiheeksi, jossa tayloristinen tieteellisen liikkeenjohdon paradigma oli vähä vähältä korvautumassa uudella joustavuusparadigmalla. Murroksessa oli kyse sekä ideologisesta uudelleensuuntautumisesta
(Castells 1996; Volberla 1998; Chandler ym. 1998) että käytännön tason organisoinneista. Joustavuus alkoi näyttäytyä toimintatapana, jolla voidaan saavuttaa kilpailuetua globaaleilla markkinoilla. Käytännöllisellä tasolla muutos ilmeni tekstiili-ja vaatetusteollisuudessa aiemman vaihetyöorganisaation muuttumisena ryhmätyöorganisaatioksi.

Suomessa tekstiili- ja vaatetusteollisuus kohtasi 1990-luvun alusta lähtien lisääntyneitä paineita toimintatapojensa muuttamiseen, kun tuonti halvan kustannustason maista lisääntyi ja vienti väheni. Yhdeksi osaksi selviytymisstrategiaansa monet yritykset omaksuivat ryhmätyöhön perustuvan työn organisoinnin. Se mahdollisti vaihtuvien ja enemmän tuotevariaatioita sisältävien mallien ja lyhyiden tuotesarjojen valmistamisen, kun taas vaihetyöhön perustuva organisaatio oli osoittautunut tehottomaksi ja kalliiksi lyhytsarjaiselle ja nopeatempoiselle tuo- 
tannolle (Lavikka 1992). Aliisan työpaikka oli yksi niistä monista yrityksistä, jotka valitsivat sellaisen selviytymisstrategian.

Pyörteinen ympäristö, joka ravisteli teollisuudenalaa, asetti myös ammattiyhdistysliikkeen uusien haasteiden eteen. Ajankohtana, johon Aliisan tarina sijoittuu, ammattiyhdistysliike oli vasta heräämässä uutta tilannetta vastaavien toimintatapojen tarpeeseen. Näin ollen vakiintumattomien strategioiden ja menettelytapojen puuttuessa pääluottamusmiehen yksilöllisen toimijuuden vaade oli tavanomaista suurempi ja toisaalta tila toimijuudelle oli tavanomaista jännitteisempi. Artikkeli kysyy: 1) Miten Aliisa loi roolinsa pääluottamusmiehenä ja miltä rooli näyttäytyi hänen elämänkaarensa valossa? 2) Mitä toimijuuden resursseja Aliisalla oli käytettävissään ja mitä rajoitteita yrityksen ja ammattiyhdistyksen erityinen tilanne asettivat toimijuudelle? 3) Miten työn vaatimukset heijastuivat Aliisan emotionaaliseen kokemukseen?

\section{TEOREETTINEN TAUSTA}

Ymmärtääksemme ruohonjuuritason ammattiyhdistysaktiivin toimintaa meidän on nähtävä ammattiyhdistykset sekä poliittisina että demokraattisina organisaatioina. Ammattiyhdistysten edunvalvontatehtävä sisältää neuvotteluja työnantajien kanssa ja yleistä yhteiskunnallista vaikuttamista. Edunvalvonnan kohdejoukko on jäsenistö, joka valitsee tyypillisesti äänestyksellä edustajansa hoitamaan puolestaan neuvotteluja. Sekä poliittisuus että demokraattisuus asettavat vaateita, jotka täyttävät niin kutsutun ahneen organisaation tunnusmerkistön (esim. Franzway 2000). Tässä yhteydessä käsitteellä on kuvattu ammattiyhdistysliikkeen piirissä vaadittavaa korkeaa sitoutumista ja lojaalisuutta, kun työ samanaikaisesti vaatii suurta työpanosta ja sisältää emotionaalista kuormaa. Toiminta vaatii akuuttien ongelmien ratkaisemista usein ristiriitojen täyttämässä ilmapiirissä, tulevaisuusperspektiivien luomista ja hereillä oloa jäsenistön mielen liikkeistä. Tällaisista tehtävistä seuraa helposti sen kaltainen työhön uppoutumisen vaade, joka ei noudata normaalin palkkatyön aika- ja paikkanormeja. Tässä artikkelissa tavoite on tarkastella resursseja ja rajoitteita, joita sen kaltainen organisaatioympäristö tarjoaa naispuolisen pääluottamusmiehen yksilölliselle ja kollektiiviselle toimijuudelle.

Ammattiyhdistysliikkeen ruohonjuuritason toimijoina luottamusmiehet tekevät työtään aivan erityisten valtasuhteiden alaisuudessa. Sosiaalitieteissä toimijuuskeskustelu on saanut vaikutteita Anthony Giddensin teoretisoinneista. Giddens kytkee valtasuhteet ja toimijuuden suoraan toisiinsa. Hänen ilmaustaan käyttäen: "toimijuus liittyy tapahtumiin, jotka yksilö aikaansaa, ensinnäkin siinä mielessä, että hän olisi voinut toimia toisinkin ja toiseksi, että mitä tahansa tapahtui, se ei olisi tapahtunut ilman yksilön interventiota" ja edelleen "se, että ihmisellä on kyky saada aikaan vaikutus olemassa olevaan asiantilaan, merkitsee sitä, että hän käyttää jonkinlaista valtaa” (Giddens 1984, 14-15). Giddensin korostama vallan ja toimijuuden saumaton yhteys tarjoaa arviomme mukaan hedelmällisiä lähtökohtia työelämän tapahtumien ja ammatillisen toimijuuden tutkimukselle (ks. myös Eteläpelto, Heiskanen \& Collin 2011).

Valta on liukas käsite. Organisaatioteoreetikko Henry Minzberg (1983, xiv) toteaa valtaa käsittelevän kirjansa esipuheessa, että "valta on arvoituksellinen ja vaikeasti tavoitettava ilmiö. Kun luulet saaneesi siitä kiinni, et voi olla varma, ettei se lipeä pois”. Englanninkielisessä kirjoittelussa vallan lajeja erotellaan usein sanaparilla power over ja power to, joista ensimmäinen kuvaa tilannetta, jossa yhdellä osapuolella on käskyvalta tai kontrollimahdollisuus toiseen osapuoleen ja toinen viittaa kykyyn saada aikaan jokin asiantila. Sanaparia on myöhemmin täydennetty myös kolmannella jäsenellä, power with. Sitä on käytetty erityisesti feministisissä analyyseissa viittaamaan kollektiiviseen kyvykkyyteen vaikuttaa asioiden tiloihin ja valtaistumisen ehtoihin (esim. Allen 2005). Tässä sovellamme Harriet Bradleyn $(1999,33)$ laveaa määritelmää, jonka mukaan valta on pystyvyyttä kontrolloida sosiaalisen vuorovaikutuksen kuvioita.

Valta toimii resurssina saada aikaan haluttuja asioita ja tapahtumia. Ammattiyhdistysliikkeen aktiivit toimivat monista aineksista muovautuvan vallan kentässä. Lise Lotte Hansen (2004) on eritellyt valtaan liittyviä resursseja, jotka soveltuvat erityisesti toimintaan ammattiyhdistysliikkeessä: 
1) materiaaliset resurssit, ts. mahdollisuudet kontrolloida rahoitusta, koulutusta, sopimusten neuvottelua, 2) asemaan liittyvä valta, toisin sanoen johtajuus ja erityisesti senioritason johtajuus, 3) kollektiivinen valta, ts. kyvykkyys mobilisoida jäsenistö, mutta myös pääsy verkostoihin ja niiden rakentamiseen, 4) henkilökohtainen valta, toisin sanoen resurssit, kuten tieto, henkilökohtainen voima, sosiaaliset kompetenssit, karisma, hyvät puheenlahjat, 5) kyvykkyys määritellä ongelmat, mielenkiinnon kohteet, arvot ja saada niille tukea. Näitä valtaan liittyviä resursseja ja niiden käyttöä säätelevät sekä yleinen tilanne talouselämässä ja yrityksessä että ammattiyhdistysliikkeen ja sen paikallisorganisaation sisäinen tilanne, mukaan lukien valtakamppailut.

Johtajuutta ammattiyhdistysliikkeen piirissä käsitelleet tutkimukset ovat tarkastelleet erilaisia strategioita ja rooleja, joilla luottamushenkilöt hoitavat tehtäviään. Eroja on löydetty muun muassa siinä, painottavatko luottamusmiehet ensisijaisesti edustamiensa jäsenten toiveiden edelleen välittämistä vai omaksuvatko he johtajaroolin, johon sisältyy edellisten tehtävien lisäksi omien aloitteiden tekemistä. Eroja on myös siinä, missä määrin he painottavat jäsenten osallisuutta ja sitoutumista päätöksentekoon (esim. Batstone 1977; Greene ym. 2000). On tärkeää ottaa huomioon, että toimijaroolin rakentaminen ruohonjuuritason tehtäviin tapahtuu arkisen palkkatyön lomassa. Siirtyminen vertaisten asemasta "joukkojen eteen" on sellaisenaan suuri roolin vaihdos, johon voi sisältyä sekä sosiaalisia jännitteitä työyhteisössä että henkilökohtaisia identiteettiristiriitoja. Myös Aliisan tarina kertoo niistä.

Luottamusmies astuu tehtäväänsä ja toimii siinä sukupuolensa ja sukupolvensa luoman kokemustaustan pohjalta. Kun puhumme sukupuolesta työelämässä, kyse on miehistä ja naisista, heidän asemastaan ja työstään työelämän rakenteissa, samanlaisuuksista ja eroista sekä eri sukupuolten välillä että samaa sukupuolta edustavien kesken. Kun työvoiman rakenne ja samalla ammattiyhdistysjäsenyyden rakenne ovat muuttuneet yleisen elinkeinorakenteen muutoksen myötä, tyyppiedustaja ammattiyhdistyksen jäsenenä ei ole enää suuressa teollisuuslaitoksessa työskentelevä mies. Rakenteelliset ja kulttuuriset siirtymät eivät kuitenkaan kulje tasatahtia. Useat tutkijat ovat päätyneet tulokseen, että ammattiyhdistysliikkeen kulttuuri on maskuliinista siten, että institutionalisoituneet maskuliiniset arvot ja normit ovat osana rakenteita, kommunikaatiota, kokousrituaaleja ja valintakäytäntöjä ja johtajuudella on maskuliininen leima (Hansen 2013; Ledwith 2013; Cunnison \& Stageman 1995). Tutkimuksista löytyy myös esimerkkejä siitä, että nämä kulttuuriset traditiot jatkuvat silloinkin, kun työvoiman rakenne muuttuu miesvaltaisesta naisvaltaiseksi (Kirsch 2013). Aliisan tarina tuo myös esille kulttuurisia piirteitä, jotka asettavat kynnyksiä naispuoliselle luottamusmiehelle.

Sukupolvikysymys suhteessa ammattiyhdistyliikkeeseen tulee vastaan julkisessa puheessa esimerkiksi huolena siitä, miten nuoret ikäpolvet ovat valmiita panostamaan yhteisten asioiden hoitoon ja toisaalta myöskin odotuksina siitä, että nuoret kykenisivät paremmin luomaan strategioita, joilla vastata tämän päivän tarpeisiin globalisoituvassa työelämässä (esim. Charlwood 2004). Sukupolven käsitettä käyttävät tutkijat korostavat, että tiettyyn aikaan syntyneet ja eläneet ihmiset jakavat joitakin yhteisiä kokemuksia, joita ei ole johonkin toiseen aikaan syntyneillä ihmisillä (Karisto 2005). Tässä artikkelissa Aliisa edustaa sodanjälkeisinä vuosina syntynyttä sukupolvea. Tutkimus työelämän sukupolvista ja muutoksissa pärjäämisen strategioista (Järvensivu ym. 2014) antoi viitteitä suuria ikäluokkia luonnehtivasta kollektiivisesta eetoksesta ja yhteisten asioiden ajamisesta, joka ilmeni pikemminkin työpaikan kehittämistoimintaan osallistumisena kuin vastarintana tai omien oikeuksien ajamisena ja vaatimisena, jota esiintyi puolestaan enemmän nuoremmilla sukupolvilla (Heiskanen 2014, Nikkanen 2014).

Ammattiyhdistysliikkeessä on tyypillistä, että aktiivit kulkevat pitkän tien johtajuuden eri portailla. Toimijuudella on ajallinen ulottuvuus; toimijuuden edellyttämät kyvyt ja luottamus tulevat testatuiksi useissa eri vaiheissa. Vaikka Giddensin määritelmä toimijuudesta sisältää vahvuuksia erityisesti valtanäkökohtien huomioimiseen, sillä on myös rajoitteensa. Kritiikkiä on esitetty muun muassa sen vuoksi, että se ei tarjoa riittäviä välineitä erotella yksilöllisten ja sosiaalisten tekijöiden merkitystä toimijuudessa. 
Myös ajallisen ulottuvuuden puute ja identiteettien merkityksen sivuuttaminen toimijuudessa on nähty rajoitteiksi Giddensin tarkastelutavassa (Eteläpelto ym. 2014, tässä numerossa). Toimijuuden ajallista ulottuvuutta on käsitelty erityisesti niin kutsutussa elämänkaaritoimijuudessa, jolla on viitattu subjektin yrityksiin vaikuttaa omaan elämäänsä pitkällä tähtäimellä (Hitlin \& Elder 2007, myös Vanhalakka-Ruoho 2014, tässä numerossa). Aliisan tarinassa kiinnitämme huomiota sekä rakenteellisiin ja kulttuurisiin tekijöihin, jotka määrittelevät puitteita pääluottamusmiehenä toimimiselle, että Aliisan elämänkaareen liittyviin subjektiivisiin tekijöihin, jotka osaltaan tekevät ymmärrettäviksi, miksi Aliisa valitsi juuri sellaisen toimintatavan kuin valitsi. Tarinan kautta näytämme Aliisan kasvua yhteiskunnalliseksi toimijaksi ja vaikuttajaksi.

\section{KUKA ON ALIISA}

Aliisa on työväenluokkainen nainen, joka on lähtöisin monilapsisesti perheestä. Työnteon hän aloitti 14-vuotiaana tukeakseen yksinhuoltajaäitiään elannon hankinnassa. Vaikka hän oli älykäs tyttö, hän ei saanut mahdollisuutta hakeutua muodolliseen koulutukseen kansakoulun käynnin jälkeen. Aliisa koki olevansa sisarustensa toinen äiti ja ajatteli, että he ovat oikeutettuja koulutukseen, jota vaille hän oli jäänyt. Nuorena aikuisena hän sai ensimmäisen ja ainoan lapsensa, jonka hän kasvatti yksihuoltajaäitinä ja huolehti, että tytär saa hyvän koulutuksen. Tutkimuksen alkaessa Aliisa oli 43-vuotias ja hän asui yksin, kun tytär oli muuttanut pois kotoa jatkaakseen yliopisto-opintoja.

Aliisan ura ammattiyhdistysaktiivina alkoi virkistystoimintavastaavana. Hän järjesti työkavereilleen käyntejä kulttuuritapahtumiin ja sai tyydytettyä samalla omaa kulttuurinälkäänsä. Tämän epävirallisen toiminnan puitteissa hän tutustui muihin työntekijöihin yrityksessä ja hänestä tuli pidetty henkilö.

Aliisalle itselleenkin yllätykseksi häntä pyydettiin asettumaan ehdokkaaksi pääluottamusmiesvaaliin, josta hän selvisi voittajana. Hän oli poliittisesti kokematon eikä hänellä myöskään ollut kokemusta ammattiyhdistysliikkeen sisäisistä valtakamppailuista. Luottamusmiesuran alussa hän oli hyvää tarkoittava ja suosittu "isosisko", joka tahtoi hyvää ympärillään oleville. Luottamusmiestyön myötä hänen kiinnostuksensa poliittisia asioita kohtaan kasvoi. Vähitellen hän päätyi sekä paikallispolitiikkaan, jossa toimi kunnanvaltuutettuna, että ammattiliiton valtakunnan tason luottamustehtäviin.

\section{TUTKIMUSMETODOLOGIA}

Tutkimuksessa on Harold Garfinkelin ajatuksiin nojautuva etnometodologinen ote, jossa on alun perin käytetty fenomenologisia käsitteitä analysoitaessa ihmisten arkitietoa ja heidän ymmärryksiään ja toimintaansa (Heritage 1996, 61, 218). Tässä tutkimuksessa tutkijoiden ja tutkittavien kokemusmaailmat limittyvät joiltakin osin. Artikkelin toinen kirjoittaja, Riitta, ja Aliisa olivat tavanneet jo aiemmin ammattiyhdistysliikkeen kautta, Riitta lehden toimittajana ja Aliisa haastateltavana. Tämä varhaisempi yhteys oli yksi osatekijä siinä, että heidän välilleen kehittyi luottamussuhde, jonka puitteissa keskustelu vaikeistakin ja henkilökohtaisesti syvästi koskettavista asioista oli mahdollista. Aliisa oli ollut jo useita vuosia päluottamusmiehenä, kun tutkimuksen kenttätyövaihe ja Aliisan haastattelut alkoivat.

Tutkimus on osa laajempaa tekstiili- ja vaatetusteollisuuteen kohdistuvaa toimintatutkimusta, jonka kuluessa tehtiin laajamittaista kenttätyötä useissa yrityksissä, mukaan lukien se yritys, jossa Aliisa työskenteli ${ }^{1}$. Monivuotisen kenttätyön yhteydessä haastateltiin yrityksen johtoa ja Aliisan työtovereita ja tehtiin observointeja sekä yrityksessä että ammattiyhdistyskontekstissa. Aliisaa haastateltiin muutaman kerran myös kenttätyövaiheen jälkeen. Tutkimusote oli laadullisen tutkimuksen asteittain syvenevä ymmärrys tutkimuskohteesta. Aineistoa kerättiin siihen saakka, että tutkimuksen edellyttämä ymmärrys kohteesta saavutettiin. Lähtökohtana olivat puolistrukturoidut haastattelut. Prosessin edetessä ja tutkimuskohdetta koskevan ymmärryksen syvetessä siirryttiin vapaamuotoisiin haastatteluihin. Kaikki aineisto nauhoitettiin ja litteroitiin. Aineistoon kuuluvat myös litteroidut havaintopäiväkirjat. Tässä pyrimme etnografiseen "tiheään kuvaukseen", joka tuo esille Aliisan tavan tehdä ymmärrettäväksi omaa kokemustaan ja antaa sille merkityksiä toimin- 
taympäristön eri elementtien jatkuvasti muuttuessa (vrt. van Maanen 1988; Geertz 1973, 9).

\section{ALIISAN TYÖPAIKKA}

Ymmärtääksemme Aliisan roolia pääluottamusmiehenä meidän on tiedettävä jotakin siitä yrityksestä, jossa hän työskenteli ja niistä haasteista, joita se kohtasi maailmanmarkkinoilla. Yleisesti ottaen kiire ja paineet näyttivät raamittavan jokapäiväisen elämän organisointia yrityksessä. Yrityksen toimitusjohtaja luonnehti tuotanto-ongelmien ratkaisuja seuraavin sanoin:

Sitä enemmän kuin ulkona valmistuttaminen kasvaa, mitä pienempiä valmistuserät ovat ja mitä enemmän meillä on tuotevariaatioita, sitä enemmän meillä on näitä sotkuisia, "epänormaaleita" tilanteita tuotannossa. Se on markkinatilanteesta johtuvaa Tämä kaaosjohtaminen on meille hyvin tuttua asiaa. Me olemme tehneet sitä jo monta vuotta.

Pääasiallinen organisaatiohaaste liittyi ryhmätyöhön ja siihen, miten ryhmät saadaan toimimaan tehokkaammin. Tutkimuksen kenttätyövaiheessa tuli ilmi, että johtajat eivät olleet osanneet ottaa ryhmätyökoulutuksessa riittävästi huomioon käytännön ongelmia ja sitä, että siirtyminen ryhmätyöhön on perustavanlaatuinen muutos (esim. Manz \& Sims 1993, 5). Palkat perustuivat edelleen urakoihin, mutta kollektiivisella pohjalla. Tämä oli radikaali muutos työntekijöiden näkökulmasta, sillä he olivat tehneet työtä yksilöllisen urakan pohjalta. Uudenlainen urakkahinnoittelu johti konflikteihin ja ristiriitoihin ryhmätyöfilosofian kanssa.

Useiden muiden alan yritysten tavoin yritys ajautui vakaviin taloudellisiin vaikeuksiin markkinatilanteen muuttuessa. Vaikeuksien ylittämiseksi yritys joutui tekemään olennaisia uudistuksia liikeideassaan ja tuotantostrategiassaan. Muutoksilla oli monenlaisia vaikutuksia työntekijöiden työhön ja asemaan, joista Aliisa pääluottamusmiesroolissaan joutui käymään neuvotteluja.

\section{LUOTTAMUSMIESROOLIN LUOMINEN}

Tarina etenee tutkijan (R) ja Aliisan (A) välisten dialogien kautta. Tässä osassa tuomme esiin, kuin- ka Aliisa hahmottelee rooliaan luottamusmiehenä ja mistä hän saa voimaa tehtäviensä hoitamiseen. Luottamusmiestehtävän lisäksi hänellä oli useita muita tehtäviä sekä ammattiyhdistysliikkeessä että paikallispolitiikassa. Yhteiskunnallisen osallistumisen kautta hänelle oli tarjolla resursseja itsensä kehittämiseen ja samalla se antoi hänelle väylän rakentaa identiteettiään yhteiskunnallisesti vaikutusvaltaisena henkilönä. Työssä hänen tehtävänsä pyörivät ryhmien palkkakehyksen ympärillä, jota hän oli ollut mukana luomassa ja kehittämässä.

R: Olen kuullut, että pienryhmien urakkapalkoissa on ongelmia. Mistä ongelmat mielestäsi johtuvat?

A: Pienryhmä ei ole yltänyt urakkapalkkaan vaan on jäänyt takuupalkan tasolle. Sanoisin, että tämä johtuu erilaisista pienryhmien ylimääräisistä tehtävistä ja järjestelyistä, jotka eivät liity varsinaiseen ompelutyöhön. Likat tekevät paljon enemmän kuin mistä heille maksetaan.

Ylimääräisillä järjestelyillä hän viittaa joihinkin uusiin tehtäviin, jotka eivät aiemmin kuuluneet vaihetyöntekijöille. Toisissa yhteyksissä on tullut esille, että siirtyminen vaihetyöstä ryhmätyöhön muuttaa työprofiileja merkittävästi (esim. Park \& Harris 2000, 159). Aliisan työpaikalla tiimiorganisaatiossa joitakin suunnittelu- ja organisointitehtäviä, jotka aiemmin olivat kuuluneet esimiehille, siirrettiin ryhmille. Niitä ei kuitenkaan otettu huomioon urakkahinnoittelussa. Palkkakysymyksen lisäksi muutoksessa oli tulkintamme mukaan kysymys identiteeteistä. Työntekijöiden ei ollut helppoa rakentaa uutta ryhmätyöhön soveltuvaa identiteettiä. Näiden paineiden ja jännitteiden keskellä Aliisa nautti työstään. Hänelle luottamusmiestehtävä oli olennainen osa hänen identiteettiään.

A: Olen omasta puolestani kokenut sen niin, että nämä ammattiyhdistysliikkeen tehtävät ja se, että olen ollut mukana neuvottelemassa pienryhmätyöhön paikallista sopimusta, ovat antaneet minulle sellaista henkistä pääomaa, jota en antaisi pois.

R: Entä mistä saat voimaa näiden tehtävien hoitamiseen? 
A: Täytyy tunnustaa, että saan iloa ihmisten auttamisesta. Se antaa voimaa. En katso aikaa, joka näihin hommiin menee. Olen valmis tulemaan aina, kun kyse on työntekijöiden puolustamisesta.

R: Olenko oikeassa, jos sanon, että tästä työstä on vähitellen tullut elämän sisältö ja merkitys sinulle?

A: No, joo. Aikuinen tyttäreni on ollutkin vihainen minulle tästä. Hän sanoo, että en elä ollenkaan itselleni ja on pyytänyt minua jättämään nämä hommat Mutta en pysty ainakaan vielä irrottautumaan näistä tehtävistä. Olen tehnyt niin paljon työtä oppiakseni tämän ja todella nautin tehdessäni työtä ihmisten hyväksi.

Keskustelun lopussa Aliisa kertoi haastattelijalle nuoruudestaan valottaakseen, miksi hän koki olevansa eräänlainen äitihahmo työyhteisössään.

A: Minä olen lähtöisin isosta perheestä... Olen heille (nuoremmille) ollut vähän sellainen toinen äitihahmo.

Tämä muista huolehtiminen on varmaan seurannut minua tänne työpaikallekin. Täälläkin haluan auttaa ihmisiä, joilla menee huonosti. Olen mukana sellaisissa kunnallisissa luottamustehtävissä, joissa voin auttaa heitä myös sitä kautta.

Mutta sen sijaan itselleni minun on vaikea pyytää apua. Täytyy olla joku iso ongelma, jos pyydän apua joltakulta.

Aliisa osoitti hyvää tarkoittavaa huolenpitoa ja hän oli vakuuttunut, että hän tiesi, mikä on hyväksi työtovereille. Ammattiyhdistysaktiivina hän näytti toimivan työtovereiden puolesta ja hyväksi, ei niinkään heidän kanssaan, mikä aiheutti ongelmia, joista lopputarina kertoo.

\section{TOIMIJUUDEN RESURSSIT}

Aliisa heittäytyi täydestä sydämestään taistelemaan työpaikkojen puolesta yrityksen talousvaikeuksien keskellä. Hän järjesti muun muassa työntekijöiden delegaatioita ministeriöihin, eduskuntaan ja rahoitusinstituutioihin. Paikallistason poliitikkona ja ammattiyhdistystoimintaan osallistuneena hän tunsi metodit ja kanavat. Hän otti käyttöön kokemuksensa, tietonsa ja kontaktinsa. Koska yritys oli paikkakunnalla merkittävä työllistäjä, myös julkinen sana oli kiinnostunut tapauksesta. Aliisa antoi haastatteluja ja tiesi, kuinka käyttää julkisuutta hyväkseen. Hän voitti taistelunsa mutta oli lopulta pettynyt ammattiyhdistyksen puuttuvaan tukeen.

R: Aloitetaan tästä taistelusta työpaikkojen puolesta Miten sinä sen koit?

A: Kyllä se oli rankkaa ja kovaa. Siinä ei ollut aikaa säästää itseään ja katsoa kelloa. Siinä oli tehtävä ja mentävä, jos meinasi jotenkin vaikuttaa siihen, että työpaikat säilyvät.

Sitten oli näitä käytännön järjestelyitä ja paperitöitä. Ensinnäkin ay-liikkeen jäsenasiat... Piti sopia ajat työvoimatoimistoon kaikille. Kaikilta piti saada allekirjoitukset valtakirjaan palkkaturvan maksamista varten. Yrityksen kanssa sitten piti neuvotella kaikki uusiksi ja sitten vielä työpaikan ulkopuolinen vaikuttaminen. Piti miettiä keihin kannattaa ottaa yhteyttä, jotka voisivat vaikuttaa työpaikkojemme säilymisen puolesta. Hain kaikki kanavat kuten KTM, Kera, poliittiset päättäjät valtakunnan ja paikallisella tasolla, lehdistö, TV ja radio. Kannanotot piti kirjoittaa ja tarkistuttaa niiden kieliasu. Ne piti myös toimittaa kaikille. Piti varata aikoja tapaamisille.

Ja ihmisillä oli hirveä hätä täällä. Minua pommitettiin kysymyksillä: Saadaanko palkat? Koska tulee työttömyysrahat? Mihin pitää ilmoittautua?

Piti olla yhteydessä eläketiedotustoimistoon, josta kävi luennoitsija kertomassa erorahoista ja työttömyyseläkkeistä. Piti selvittää aikuiskoulutuksen vaihtoehtoja.

Kaikki tämä piti hoitaa ja selvittää lyhyessä ajassa. Sen sijaan että Aliisa olisi saanut tukea, ammattiliitto kritisoi häntä paikallisen sopimuksen hyväksymisestä. Hänellä oli tunne, että ammattiliitto sokeutui sisäisiin valtakamppailuihinsa eikä kyennyt näkemään ja tunnistamaan työpaikkojen menettämisen uhan vakavuutta. 
A: Ammattiliiton syytökset, että olisin menetellyt väärin paikallisessa sopimisessa, yllättivät minut täydellisesti. Olin odottanut liitolta tukea ja jouduinkin aivan päinvastaiseen tilanteeseen. Tämä toi minulle aika ikävän tunteen.

R: Miten toverit työpaikalla suhtautuivat? Eivätkö he tukeneet sinua? Millainen yhteishenki teillä oli?

A: Minun täytyy sanoa, että olen ehkä niin vahva persoona jo nyt, kun olen hoitanut tätä tehtävää 12 vuotta ja lisäksi ollut kunnallisissa luottamustehtävissä. Olen tottunut ottamaan kiinni asioihin ja tiesin mihin piti ottaa yhteyttä. Mutta kyllä työkaverit olivat taustatukena, henkisenä tukena.

Ja ei siinä voinut jäädä odottelemaan, vaan oli toimittava heti. Siinä täytyi vain kylmästi soittaa, varata aikoja ja mennä esittämään asiansa joka puolelle. Lopuksi meni sellaiseksi, että media piiritti minua niin, että jouduin jo sanomaan, että älkää enää, otan yhteyttä kun on kerrottavaa.

R: Näkyykö yhteishenki vielä (kun yrityksen toiminta on järjestetty uudelleen)?

A: No ei täällä enää välttämättä ole sellaista yhteishenkeä. Ja sehän on vain luonnollista. En minä sitä sillä tavalla odottanutkaan. Kun meillä on ollut perinteisesti alan keskipalkkatasoa paremmat palkat ja erilaisia etuja täällä. Nyt aloitettiin uudelta pohjalta ja puhtaalta pöydältä. Vanhaan ei voi enää vedota. Oli jo suuri saavutus, että kaikki pääsimme töihin vanhoina työntekijöinä. Mutta palkoissa tuli takapakkia. Ainakin hetkellisesti näin on asia. Uskon kyllä, että me tästä vielä nousemme palkkauksellisesti, kun on annettu näyttö, että saadaan tuottavuus nousemaan. Valitettavasti henkilökunta ei tätä käsitä.

Tulkitsemme keskustelun seuraavalla tavalla: Aliisa oli voittanut toisten puolesta käymänsä taistelun mielessään epämääräinen usko siihen, että hän saisi ymmärtämystä toisilta työntekijöiltä, jotka eivät kuitenkaan todennäköisesti tienneet uhkaavan tilanteen yksityiskohtia eivätkä sitä, mitä Aliisa oli tehnyt heidän puolestaan. Hän oli ollut kenraali vailla joukkoja, eikä hän ollut itse laskenutkaan mitään toisten työntekijöiden tuen varaan. Hän oli tottunut toimimaan yksin ja käyttämään mediaa hyväkseen saadakseen sympatioita taistelulleen. Työtovereiden silmissä hän oli lähinnä tehnyt itsestään julkisuuden henkilön. Mutta nyt Aliisa vaikutti surulliselta ja yksinäiseltä tehtaalla.

A: Kyllä tässä on nyt niin paljon vaikeuksia käsissäni Nyt on tullut osastojen välille kauhea kateus ja ristiriita. Kaikki tällainen on hyvin raskasta. Tuntuu välistä, että en saa langan päästä itsekään kiinni, että millä tavalla mitään voisi asioita auttaa Jokainen vain ajattelee, että miksi tuo saa pennin enemmän kuin minä. Ja miksi tuo saa tehdä samaa työtä, kun minun pitää mennä ja vaihtaa. Jokainen ajattelee vain itseänsä.

Aliisan ääni oli väsynyt, kun hän puhui tunnelmista, joita työntekijöiden mielipiteet alentuneista palkoista synnyttivät. Tilanne uusissa tiimeissä oli erityisen vaikea. Katkeruus palkka-alennuksista ei luonut otollista pohjaa työntekijöille opetella uusia työtapoja, koneita ja tiimityömuotoja.

A: Nämä asiat ovat nousemassa nyt kuumiksi yrityksessä. Meidän pitäisi vielä jaksaa selviytyä tästä ja sitten tilanteen normalisoiduttua, kun on saatu puihin tämä organisaatio, nämä työt ja muutokset, niin sitten voidaan ajatella tilanteen rauhoittuvan. Minulla on luottamus yrityksen johtoon. Heidän täytyy aloittaa varovaisesti ja he aloittavat matalalla profiililla. On vaikeaa tässä tilanteessa saada heiltä lisää rahaa työntekijöille. Meidän täytyy näyttää tulosta ensin. Kun ollaan positiivisella puolella, myös työntekijöille voidaan saada jotakin lisää.

On syytä huomata, että sana "me" viittaa Aliisan puheessa häneen itseensä ja yrityksen johtoon. Kaaoksen ja työkavereiden vihamielisten reaktioiden keskellä hän sanoo: "Ainakin voin luottaa häneen (johtajaan). Mitä hän sanoo, sen hän tekee. Hän on tiukka mutta rehellinen. Jos hän olisi toisenlainen, minulla ei olisi voimia taistella tätä läpi myöskään työpaikkatasolla”.

R: Minusta on outoa, että olet näin yksin ongelmien keskellä. Se näyttää jopa vaaralliselta. Eikö täs- 
sä pitäisi olla aktiivien ryhmä jakamassa vastuuta kanssasi?

A: Olen tätä ajatellut. Ja olen toivonut apua liitoltakin. Mutta väkisin on tällaista mahdoton kehitellä.

Nämä tapahtumat osuivat samaan aikaan, kun uusi vaalikierros luottamusmiespaikoista oli käynnissä. Aliisa luotti toiminnassaan "sisarten" väliseen kiintymykseen ja lojaalisuuteen. Hän oletti sellaisen suhteen vallitsevan itsensä ja kanssatyöntekijöidensä välillä. Hänen virheensä oli kuitenkin ottaa tämä side selviönä. Hän ei saanutkaan vastakaikua valintatilanteen taustalla vaikuttaneen valtakamppailun vuoksi.

\section{YKSINÄINEN TAISTELU}

Noin kolme kuukautta näiden tapahtumien jälkeen Aliisa soitti ja kertoi uutisen. Hän oli hävinnyt täpärästi äänestyksen pääluottamusmiespaikasta. Hän oli masentunut ja hänen äänensä vaikutti voipuneelta. Hänen tilanteensa näytti samankaltaiselta kuin Orbach \& Eichenbaumin (1994) ja Miner \& Longinon (1987) kuvaamat tapaukset, joissa naiset ovat vahvan emotionaalisesti sitoutuneet ajamaan jotakin asiaa ja kärsivät usein pitkiä aikoja haavoista, joita valtakamppailut ovat aiheuttaneet. Ikään kuin naisten välistä sidosta etsien Aliisa sanoi Riitalle puhelimessa kertoessaan vaalin tuloksesta:

A: Itse asiassa sinä olet melkein ainoa, joka on ymmärtänyt ja auttanut minua. Olen saanut sinulta eniten apua tämän sotkun aikana ja olen oppinut paljon pienry hmistä. Olet ymmärtänyt minua ja olen voinut jutella kanssasi kuin vertaiselle. Se on ollut minulle suuri apu.

Seuraava tapaaminen oli Aliisan hotellihuoneessa ammattiliiton kokouksen aikana kolme viikkoa näiden surullisten uutisten kuulumisen jälkeen. Kaksi muuta keskustelijaa olivat kokeneita ammattiyhdistysaktiiveja ja luottamusmiehiä. Tämä keskustelutilanne paljastaa jotakin ammattiyhdistystoiminnan vähemmän tunnetusta puolesta. Hiljaisissa hotellihuoneissa liiton kokousten aikana naiset kerääntyvät yhteen hävittyjen taistelujen jälkeen itkemään ja lohduttamaan toisiaan. Näissä naisten nurkkauksissa voidaan havainnoida emotionaalisen rationaliteetin ilmentymiä (esim. Bologh 1990; Mumby \& Putnam 1992; Lavikka 1997).
Maria (M) ja Leena (L) olivat tavanneet Aliisan jo viikkoa aiemmin ja niin ollen he tiesivät tilanteesta. He olivat huolissaan Aliisasta ja tunsivat auttamis- ja huolehtimisvastuuta. Tässä keskustelussa he yrittivät kiinnittää huomiota Aliisan tapaan hoitaa taistelua työpaikkojen puolesta. Heidän näkemyksensä mukaan syy luottamusmiespaikan menettämiseen löytyy sieltä. He pyrkivät saamaan Aliisan huomaamaan oman tapansa toimia.

A: Paine oli niin kova, että en kyennyt näkemään enää mitään. Paloin loppuun, masennuin.

M: Tässä kyllä yksi avainkysymys mielestäni on se, että kenen taistelu tämä sitten loppujen lopuksi oli. Oliko se sinun taistelusi? Mietitkö sitä? Lähditkö sinä siihen väärillä motiiveilla? Et varmaankaan omalta kohdaltasi. Sitä en epäile hetkeäkä̈n. Mutta kun katsoo ulkoa päin, niin on pakko kysyä, että kenen taistelua tämä todellisuudessa on. Minä luulen, että sinä taistelit ensinnäkin itsesi vuoksi. Kyllä sinulla siellä on sellainen kunniakysymys, että sinä haluat nyt tehdä. Olla vähän kuin Äiti Teresa. Tosiaankin, itsekin teen sitä samaa toisinaan. Sitten taistelit näiden työkavereiden puolesta, kaikkien, sen koko porukan. Siinä tulee esiin sellainen emotyyppi. Sitten taistelit sen pirun työnantajan puolesta kaikkein eniten. Se siitä kaikkein eniten hyötyi ja ehkä kaikkein eniten menetti.

A: Mä en osaa sitä teille likat kuvata sitä kiireaikataulua. Minä olen kuunnellut, miten teillä on ammattiosastot taustalla. Teillä on toisenlainen tuki kuin minulla. Suuri määrä työpaikkoja oli uhattuna ja viikko oli aikaa, kun tämä tilanne tuli. Voin vilpittömästi sanoa, vaikka olen virheitäkin tehnyt, että kyllä minulla oli huoli niistä työpaikoista. En minä äiti Teresana mihinkään mennyt.

L: Kyllä jokainen tajuaa, että sinulle oli se kaikkein tärkeintä. Kyllä sen tekee sen vuoksi, että ne työpaikat säilyisivät.

A: Meillä ei sillä seudulla ole paljon valinnan varaa. Me olemme kouluttamattomia ja meillä on perheet ja kaikki. Se tuli siinä voimakkaana. Yritin kyllä puhua varapääluottamismiehelle ja ammattiosaston puheenjohtajalle, että pidetään tiedotustilai- 
suuksia ja he kertoisivat siellä väelle. He eivät sitä koskaan tehneet. Se väki ei tiedä.

L: Sen olisi pitänyt pelata koko ajan, että väki olisi tiennyt, että nyt on Aliisa eduskunnassa hakemassa tukea ja koko ajan olisi pitänyt tiedottaa työntekijöille, mitä sinä olit milloinkin tekemässä.

A: Esiinnyimme sillä tavalla, että mukana oli aina edustus kaikista henkilöstöryhmistä. Aina puhuttiin koko henkilöstöstä.

L: Tästäkin sanoisin, että se porukka on saattanut kokea sen niin, että se on jäänyt ulkopuolella koko hommasta.

M: Sitä minä juuri tarkoitin. Syntyy juuri sellainen asetelma.

L: Se on ihan selvää, että Aliisa ei sitä yksin pystynyt. Hän ei voinut sitä kenellekään delegoida, että sinä hoidat työpaikalla tämän ja pidetään koko ajan yhteyksiä.

M: Tällainen ammattiyhdistyksen taistelu ei saa olla yhden ihmisen sotaa.

A: Me emme olleet tällaiseen valmistautuneita. On pieni paikka. Olet tullut tehtaalle neljäntoista vanhana kakarana ja siellä saanut olla. Ja kaikki muutkin ovat samalla tavalla olleet. Ei ole tarvinnut tällaisista huolehtia. Minä olen kuunnellut teitä, jotka olette käyneet läpi konkursseja ja minä olen luullut, että olen jotakin ymmärtänyt. Mutta nyt sanon, että en täydelleen ymmärtänyt ennen kuin olen tämän käynyt läpi.

M: Sanoisin sinulle sen verran, että totta kai sitä vaikeissa oloissa tekee virheitä. Se pitää itsekin hyväksyä. Ei saa olla liian kriittinen itseään kohtaan.

\section{A: En olekaan niistä asioista.}

L: Sinä puhutkin jo huomattavasti eri tavalla kuin viimeksi.

A: (Alkaa itkeä) Mutta tämä on niin tuskallista. Minulla on nämä asiat. En pääse eroon niistä pahoista asioista, jotka ovat minuun kohdistuneet. Olen ollut niin tiukassa tilanteessa ja olen kuitenkin yrittänyt tehdä sen minkä osasin ja pystyin. Kaikki ne nimittelyt ja soitot. Ja kaikki paha aina vain kertaantuu.
L: Omaa tuskaansa ne purkavat sillä tavalla, että pääsevät toiselle sanomaan. Kyllä minäkin olen tuota kokenut.

M: Juuri tuollaisena aikana ne kaikkein heikoimmat ihmiset erottuvat. Silloin tulee esiin ihmisten vahvuus ja heikkous. Silloin näet, ketkä on todella sellaisia. Joskus tulee sellaisia hyviä palautteita, jotka yllättävät. Joku ihminen voikin olla niin paljon isompi ihminen.

A: Minä tajuan tämän. Minä käyn nyt tunteenomaista prosessia. Menin lääkärin puheille. Olin kerta kaikkiaan lopussa. Lääkäri puhui jotakin surutyöstä. Ja minusta todella tuntuu kuin kuolema olisi käynyt, kun minulla ei yksinkertaisesti ole ollut mitään muuta kuin tämä ammattiyhdistystyö ja toiminta pääluottamusmiehenä toisten hyväksi. He olivat minun perheeni. Itken heitä. Tuntuu kuin heidät olisi otettu minulta pois En koskaan elämässäni ole ollut näin huonossa jamassa.

M: On hyvä itkeä, kun on surua. Sitä ei pidä hävetä. Minusta tuntuu, että olet jo liikkunut askeleen eteenpäin. Puhut jo eri tavalla kuin viime viikolla. Sinun pitää vain luottaa siihen, että tämä menee pian ohi.

\section{JOUSTAVUUDESTA ULKOISTUKSIIN}

Kappalemääriin pohjautuva urakkapalkkaus synnytti jatkuvasti tyytymättömyyden tunteita työntekijöissä. Yrityksen johto ei ollut halukas kehittämään aikapalkkaukseen perustuvaa järjestelmää. Työntekijät kokivat, että heidän panostaan ei arvostettu ja että heidän työsuhteensa olivat epävarmat. Työntekijät kehittivät taitojaan monitaitoisuuden suuntaan, mutta se ei lopulta auttanut heitä työpaikkojen säilyttämisessä. Yritys päätti, että ainoastaan lyhimmät sarjat, joissa oli lyhimmät läpimenoajat, valmistettaisiin jatkossa Suomessa. Yrityksen johdon näkemys oli, että kotimainen tuotanto ei ole kilpailukykyistä ilman ulkoistuksia. Näin ollen kotimainen joustava tuotantokaan ei turvannut yrityksen taloudellista toimintakykyä. Yritys päätti työvoiman vähennyksistä. Tässä vaiheessa pääluottamusmiesasema ei enää suojannut Aliisaa ja hän oli yksi irtisanotuista. Ennen näitä tapahtumia Aliisa oli työskennellyt pari vuotta tavallisena lattiatason työntekijänä. Hänellä oli vielä joitakin ammattiyh- 
distystehtäviä jäljellä, joihin hän pyrki paneutumaan resurssiensa rajoissa, mutta yleisesti hänestä tuntui, että hänen osaamisensa ja tietonsa menivät hukkaan.

Pari vuotta irtisanomisensa jälkeen Aliisa virkistyi ja löysi energisen minuutensa. Hän antautui toisenlaiseen yhdistystoimintaan, jossa saattoi jälleen auttaa muita ihmisiä. Viimeisessä tutkimushaastattelussa Aliisa sanoi: "Nämä viimeiset kolme vuotta ovat olleet elämäni parasta aikaa".

\section{DISKUSSIO}

Artikkelissa on tehty seuraavat kysymykset: 1) Miten Aliisa loi roolinsa pääluottamusmiehenä ja miltä rooli näyttäytyi hänen elämänkaarensa valossa? 2) Mitä toimijuuden resursseja Aliisalla oli käytettävissään ja mitä rajoitteita yrityksen ja ammattiyhdistyksen erityinen tilanne asettivat toimijuudelle? 3) Miten työn vaatimukset heijastuivat Aliisan emotionaaliseen kokemukseen?

Artikkelin toimijuuskäsite on saanut vaikutteita Anthony Giddensin (1984) näkemyksistä, joiden mukaan valta ja toimijuus ovat sidoksissa toisiinsa. Pääluottamusmies toimii monenlaisen vallan kentässä sekä vallan alaisena että vallan suomin resurssein varustettuna. Koko tekstiili- ja vaatetusteollisuuden yleinen tilanne ja yrityksen erityinen tilanne loivat rajaehdot Aliisan kasvulle yhteiskunnalliseksi toimijaksi ja määrittelivät sen kentän, jossa hän toimi työntekijöiden luottamushenkilönä ja toteutti neuvottelutoimintaa työnantajan kanssa. Paikallinen ammattiosasto, työhuonekunta ja niiden jäsenistö, eli Aliisan työtoverit määrittelivät puolestaan viime kädessä Aliisan toiminnan valtuuksien rajat. Tämä vallan kenttä sääteli olennaisesti mutta ei tyhjentävästi Aliisan toimijuutta. Tarinan dynamiikka jäisi puutteelliseksi, jos jättäisimme huomiotta hänen henkilökohtaisen historiansa ja roolinsa vaikutusvaltaisena kansalaisena. Tämä näkökulma toimijuuteen liittää artikkelin myös elämänkaaritoimijuutta (Hitlin \& Elder 2007) käsitelleiden pohdintojen piiriin. Giddensin ajattelun ja elämänkaaritoimijuusnäkökulman käyttäminen teoreettisina välineinä ovat tarjonneet tarinan kertomiselle toisiaan täydentävät lähtökohdat. Niiden avulla olemme avanneet sekä toiminnan yhteiskunnallis-

\section{P ÄÄLUOTTAMUSMIES}

\section{TOIMII MONENLAISEN}

VALLAN KENT $\ddot{A S S A ̈}$

SEK ̈̈ VALLAN ALAISENA

ETT ̈̈ VALLAN

\section{SUOMIN RESURSSEIN}

\section{VARUSTETTUNA.}

ten resurssien ja rajoitteiden maailman että Aliisan yhteiskunnalliseksi toimijaksi kasvamisen persoonallisen ulottuvuuden.

Voimme sanoa, että 12-vuotisen pääluottamusmieskautensa aikana Aliisa ilmensi vahvaa toimijuutta. Hänellä oli visioita paremmista työn ehdoista ja olosuhteista ja ajatuksia siitä, miten ne voisi saavuttaa. Hän otti myös aktiivisesti kantaa asioihin, teki aloitteita ja tarpeen vaatiessa käytti myös yleisemmän yhteiskunnallisen vaikuttamisen keinoja. Hän heittäytyi toimintaan sekä teoillaan että emootioillaan. Hänen tekemisen tapansa oli pikemminkin yksilöllinen kuin kollektiivinen, mikä teki hänen asemansa haavoittuvaksi.

Yrityksen tilanteen kriittisissä vaiheissa Aliisa toimi itseään säästämättä työpaikkojen pelastamiseksi. Voisi hyvinkin luonnehtia, että hänen toimintansa vastasi tilanteen vaatimuksia mutta toisaalta hänen käytettävissään olleet resurssit eivät olleet sillä tasolla, mitä vaikea tilanne olisi edellyttänyt. Puuttuva tuki ammattiyhdistyksen suunnalta oli yksi puoli vaatimusten ja resurssien epäsuhtaa ja toinen, Aliisan kannalta vielä tärkeämpi asia, oli työtovereiden tuen puute. Vaikkakin häviö äänestyksessä luottamusmiespaikasta oli täpärä, se kuitenkin kertoi, että hän ei ollut kyennyt saamaan taakseen riittäviä kollektiivisen vallan resursseja.

Aliisan yksilöllinen pelastajarooli kostautui siinä vaiheessa, kun neuvotteluissa työpaikkojen säilyttämiseksi joistakin saavutetuista eduista jouduttiin tinkimään. Tämä synnytti suuttumusta ja turhautumista työtovereissa, ja negatiiviset tunteet kanavoituivat Aliisaan. Asiaa ei lieventänyt työntekijöiden mielessä se, että tilanne oli pitkälti seurausta alan yritysten 
yleisemmistä toimintaehdoista. Toimintaehtojen muuttumisen varalle ammattiyhdistyksellä ei ollut toimintastrategiaa ja kriittisyys oli helpompi suunnata henkilöön kuin lähteä miettimään joltakin täysin uudelta kantilta edunvalvonta-asioita.

Ammattiyhdistyksen sijaan Aliisa tukeutui toiminnassaan sisaruuteen resurssina. Halu pitää huolta "sisarista" oli Aliisan toiminnan hallitseva motiivi. Kun otamme huomioon hänen elämänhistoriansa, sen kaltainen orientaatio ei ole yllättävä. Tulos vertautuu hyvin naisilla havaittuihin emotionaalisen rationaliteetin korostuksiin sekä ammattiyhdistysliikkeen piirissä (Ledwith 1990) että muilla aloilla (esim. Bologh 1990; Mumby \& Putnam 1992).

Tutkimuksessa nousee esille työtovereiden negatiiviset tunteet, joista muodostui este tuelle. Organisaatioita koskevissa tutkimuksissa naisten väliset negatiiviset emootiot ovat kaiken kaikkiaan varsin vähän käsitelty aihe (esim. Orbach \& Eichenbaum 1994; Miner \& Longino 1987). On varsin ymmärrettävää, että muutokset työn sisällöissä, huolet palkkatasosta ja pelko työn loppumisesta synnyttävät voimakkaita emotionaalisia reaktioita. Sellaiset olosuhteet voivat johtaa Norman Denzinin (1984, 224-225) kuvauksen mukaiseen negatiivisen henkisen ilmaston syntymiseen, joka kääntyy läheisiä tunnekohteita, usein äiti- tai isähahmoja, vastaan. Aliisan tapauksessa, jossa hän oli sekä työkaveri että ammattiyhdistyksen edustaja, syntipukkiroolin edustajaksi joutuminen sai aikaan kauaskantoiset seuraukset. Vaikka Aliisalla oli pitkältä ajalta kosolti meriittejä työkavereidensa asioiden ajamisesta, hän sai kantaakseen negatiivisten emootioiden kuorman yrityksen talousvaikeuksien jälkeisessä sekavassa tilanteessa ja menetti lopulta sekä luottamusmiespaikkansa että työnsä.

Tarinaan sisällytetty reflektiivinen keskustelu Aliisan ja kahden muun ammattiyhdistysaktiivin välillä täsmentää vielä sitä erityislaatuista vallan kenttää, jossa pääluottamusmies tekee työtään. Marian kysymys "Kenen taistelu tämä oli ensisijaisesti?" johdattaa miettimään päluottamusmiehen työn perusluonnetta. Tilanteessa, jossa ammattiyhdistys oli valmistautumaton vastaamaan uuden tuotantotavan haasteisiin, on ymmärrettävää, että työntekijöiden tulevaisuusperspektiiveistä syvästi huolta kantava Aliisa valitsi vahvan yksilöllisen toimijuuden, kun kollektiiviselle toimijuudelle ei näyttänyt löytyvän vastuunkantajia. Siitä huolimatta pääluottamusmiehen tehtävä on sellainen, että omistautuminen ja huolenpito eivät riitä ellei sillä, joka luottamustehtävän on saanut, säily kaiken aikaa tuntuma niiden tunteisiin ja toiveisiin, jotka luottamuksen ovat antaneet. Tutkimus ei kuitenkaan anna vastausta siihen, millaisella pääluottamusmiesroolilla tulos työntekijöiden kannalta olisi ollut parempi kuin Aliisan tavalla. Jälkikäteen tarkasteltuna Aliisan tilalle valittu luottamusmies ei myöskään kyennyt kääntämään kehityksen pyörää toiseen suuntaan: työpaikkoja menetettiin ja tuotantoa siirrettiin halvan kustannustason maihin.

\section{JOHTOPÄÄTÖKSET}

Toimijuus samoin kuin valta ovat kontekstuaalisia ilmiöitä. Aliisan tarinassa on useita eritasoisia ja toisiinsa nähden sisäkkäisiä konteksteja. Tuotantotapojen ja maailmanlaajuisen työnjaon muutos vaikuttavat työnteon ehtoihin ympäri maailmaa. Artikkelissa tarkasteltu tekstiili- ja vaatetusteollisuus oli tayloristisen ja joustavan tuotannon murrosvaiheessa. Vastaavat tuotannon ehtojen muutokset ovat koskettaneet ja koskettavat useita muitakin teollisen tuotannon aloja. Tutkimusajankohtana murroksen laajuus ja syvyys oli uusi asia, jonka varalle ammattiyhdistysliikkeessä ei oltu luotu tilanteeseen sopivia edunvalvonnan strategioita. Paikallisen tason ammattiyhdistysaktiivit olivat vailla kollektiivisten prosessien antamaa tukea. Tarinassa yksi läpäisevä juonne onkin yksilöllisen ja kollektiivisen toimijuuden jännite.

Kollektiivisella toimijuudella tarkoitetaan tässä yhteydessä ammattiyhdistysliikkeen toimintaa työntekijöiden etujen puolustamiseksi. Aliisan tarinan taustalla näkyy intressin uudelleentulkinta. Perinteisesti ammattiyhdistysliikkeessä päluottamusmies asemoidaan työntekijöiden etujen ja oikeuksien puolustajaksi. Aliisan oli kuitenkin ymmärrettävä intressi laajempana. Yrityksen tilanteen kompleksinen muutos nosti esiin työpaikkojen säilyttämisen. Aliisa etsi liittolaisia kamppailulleen toisista yhteiskunnallisista toimijoista, mukaan lukien työnantajasta. Tätä eivät sen enempää ammattiliiton johtoporras kuin työtoveritkaan voineet täysin ymmärtää. 
Toinen taustalla oleva juonne on ammattiyhdistysliikkeen kulttuuri toimintatiloja antavana tai rajoittavana tekijänä. Tutkimuksen avaamasta ikkunasta näyttää siltä, että ammattiyhdistysliikkeen sisäisessä kulttuurissa miehillä ja naisilla on omat tilansa paitsi symbolisesti myös aivan konkreettisesti esimerkiksi kokouskäytännöissä. Maskuliininen tarina syntyy formaalien ja informaalien kokousten näyttämöillä. Feminiininen tarina puolestaan näytellään kokouspaikkojen hiljaisissa nurkkauksissa, joissa naiset purkavat kokemuksiaan, huoliaan ja tunnetilojaan.

Toimijuuden tutkimisen kannalta tarinan esille tuoma kontekstien ja prosessien monitasoisuus on suuri haaste. Tämän tarinan kertomisen teki mahdolliseksi usean vuoden aikana tehty etnometodologinen tutkimus tekstiili- ja vaatetusteollisuuden yrityksissä ja Aliisan haastattelut tutkimusten kenttätyön eri vaiheissa. Pitkäkestoisen, luottamuksellisen tutkimussuhteen luominen teki myös mahdolliseksi käsitellä tutkimuksessa vahvoja tunnetiloja ja "syyllisten" etsintää, jotka rajuissa muutostilanteissa ovat tavallisia, mutta joita koskevat tutkimukset ovat vähäisiä.

Toimijuusnäkökulmasta tarinassa on sekä surullinen että rohkaiseva sävy. Toiminnassaan Aliisa näyttäytyi aloitteellisena ja aikaansaavana ihmisenä, joka käytti tilanteen vaatimia vaikutuskanavia tavoitteidensa saavuttamiseksi. Yksi osa tarinaa päättyy siihen, että Aliisa, joka oli laittanut itsensä täysillä likoon 12 vuoden ajan, päätyy työttömien jonoon yhdessä työtovereidensa kanssa. Tarinan uusi alku on jälkikirjoituksessa, jonka mukaan Aliisa oli löytänyt paikkansa yhdistystoiminnan piiristä, jälleen voimakkaana, toisten eteen työtä tekevänä ihmisenä.

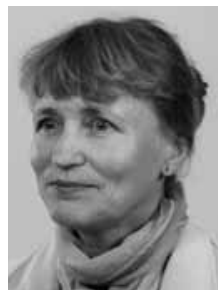

Tuula Heiskanen

YT, dosentti, tutkimusjohtaja Työelämän tutkimuskeskus Tampereen yliopisto

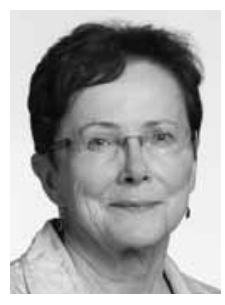

Riitta Lavikka

$Y T$, dosentti, toimittaja, tutkija Työelämän tutkimuskeskus Tampereen yliopisto 
Allen, A. (2005). Feminist perspectives on power. Stanford Encyclopedia of Philosophy. [plato. stanford.edu/entries/feminist-power], luettu 24.11.2010.

Batstone, E., Boraston, I. and Frenkel, S. (1977). Shop Stewards in Action. Oxford: Basil Blackwell.

Bologh, R.W. (1990). Love or Greatness. Max Weber and Masculine Thinking - A Feminist Inquiry. London: Unwin Hyman.

Bradley, H. (1999). Gender \& Power in the Workplace. London: MacMillan Press.

Castells, M. (1996). The Rise of the Network Society. Volume I. Oxford: Blackwell Publishers.

Chandler, A.D., Hagström, P. and Sölvell, Ö. (1998). The Dynamic Firm. The Role of Technology, Strategy, Organization, and Regions. Oxford and New York: Oxford University Press.

Charlwood, A. (2004). The new generation of trade union leaders and prospects for union revitalization. British Journal of Industrial Relations, 42 (2), 379397.

Cunnison, S. \& Stageman, J. (1995). Feminising the Unions. Aldershot: Avebury.

Denzin, N.K. (1984). On Understanding Emotion. San Francisco, Washington and London: Jossey-Mass Publishers.

Eteläpelto, A. ym. (2014). Mistä ammatillisessa toimijuudessa on kyse? Aikuiskasvatus 34(3) 202-214 Eteläpelto, A., Heiskanen, T. \& Collin, K. (2011). Vallan ja toimijuuden monisäikeisyys. Teoksessa A. Eteläpelto, T. Heiskanen \& K. Collin (toim.) Valta ja toimijuus aikuiskasvatuksessa, Vantaa: Kansanvalistusseura ja Aikuiskasvatuksen tutkimusseura, 9-30.

Franzway, S. (2000). 'Women working in a greedy institution: Commitment and emotional labour in the union movement'. Gender, Work and Organization, 7(4), 258-268.

Geertz, C. (1973). The Interpretation of Cultures. Selected Essays. New York: Basic Books.

Giddens, A. (1984). The Constitution of Society. Berkeley: University of California Press.

Greene, A-M., Black, J. \& Ackers, P. (2000). 'The union makes us strong? A study of the dynamics of workplace union leadership at two UK manufacturing plants'. British Journal of Industrial Relations, 38(1), 75-93.

Hansen, L.L. (2004). Ligestillingspolitiske problemer - og mulige losninger. Kon, magt og forandring i LO og UNISON. Roskilde: Roskilde University, Department of Social Sciences.

Hansen, L.L. (2013). Women leaders riding the whirlwind: Leadership and gender in/equality in the Danish labour movement. Teoksessa Ledwith, S \& Hansen, L.L. (toim.) Gendering and Diversifying Trade Union Leadership, New York: Routledge, 67-90.

Heiskanen, T. \& Lavikka, R. (2013). Flexible production and flexible women. The story of union leader Alice. Teoksessa Ledwith, S. \& Hansen, L.L. (2013) Gendering and Diversifying Trade Union Leadership, New York: Routledge, 117-137.

Heiskanen, T. (2014). Suurten ikäluokkien profiili. Teoksessa Järvensivu, A., Nikkanen, R. \& Syrjä, S. (2014) Työelämän sukupolvet ja muutoksissa pärjäämisen strategiat. Tampere: Tampere University Press, 210-221.

Heritage, J. (1996). Harold Garfinkel ja etnometodologia [Translation from Garfinkel and Ethnomethodology]. Jyväskylä: Gaudeamus.

Hitlin, S. \& Elder, G.H. (2007). Time, self and the curiously abstract concept of agency. Sociological Theory, 25 (2), 170-191.

Järvensivu, A., Nikkanen, R. \& Syrjä, S. (2014). Työelämän sukupolvet ja muutoksissa pärjäämisen strategiat. Tampere: Tampere University Press.

Karisto, A. (2005.) Suuret ikäluokat kuvastimessa, teoksessa Karisto, A. (toim.) Suuret ikäluokat, Tampere: Vastapaino, 17-58.

Kirsch, A. (2013). Union revitalisation through gender equality in the German service sector union Ver. di. Teoksessa Ledwith, S \& Hansen, L.L. (toim.) Gendering and Diversifying Trade Union Leadership, New York: Routledge, 222-244.

Lavikka, R. (1992). Ryhmätyö tulee vaatetusteollisuuteen, Työraportteja 29/1992. Tampere: Tampereen yliopisto, Työelämän tutkimuskeskus.

Lavikka, R. (1997). Big Sisters. Spacing Women Workers in the Clothing Industry. A Study on Flexible Production and Flexible Women, Research Institute for Social Sciences, Work Research Centre, T Series 16/1997. Tampere: University of Tampere. 


\section{VIITTEET}

Ledwith, S. (2013). Doing, un-doing and re-doing gendered union leadership, Teoksessa Ledwith, S \& Hansen, L.L. (toim.) Gendering and Diversifying Trade Union Leadership. New York: Routledge, 91-116.

Ledwith, S., Colgan, F., Joyce, P. and Hayes, M. (1990). 'The making of women trade union leaders'. Industrial Relations Journal, 21(2): 112-125.

Manz, C.C. and Sims, H.P. (1993). Business Without Bosses. How Self-Managing Teams Are Building HighPerformance Companies. New York, Chichester, Brisbane, Toronto and Singapore; John Wiley \& Sons.

Miner, V. and Longino, H. (eds) (1987). Competition. A Feminist Taboo? New York: The City University of New York.

Mintzberg, H. (1983). Power in and Around Organizations. Englewood Gliffs: Prentice-Hall.

Mumby, D.K. and Putnam, L.L. (1992). 'The politics of emotion: A feminist reading of bounded rationality'. Academy of Management Review, 12(3): 465-486.

Nikkanen, R. (2014). Hyvinvoinnin sukupolven profiili, teoksessa Järvensivu, A., Nikkanen, R. \& Syrjä, S. (2014) Työelämän sukupolvet ja muutoksissa pärjäämisen strategiat, Tampere: Tampere University Press, 228-238.

Orbach, S. and Eichenbaum, L. (1994). Between Women. Love, Envy and Competition in Women's Friendship. London: Arrow.

Park, B. and Harris, R. (2000). 'Roles and responsibilities of team leaders and members: $A$ case study of the Australian automotive industry'. Teoksessa Procter, S. and Mueller, F. (toim.) Teamworking. London: MacMillan Business, 143-161.

van Maanen, J. (1988). Tales of the Field. On Writing Ethnography. Chicago and London: The University of Chicago Press.

Vanhalakka-Ruoho, M. (2014). Toimijuus elämänkulussa. Aikuiskasvatus 43 (3), 192-201

Volberda, H.W. (1998) Building the Flexible Firm. How to Remain Competitive. Oxford: Oxford University Press.
1 Julkaisussa Lavikka (1997) on analysoitu mm Aliisan työpaikan osalta, miten naisten työyhteisö käsittelee muutosta, ja julkaisussa Heiskanen \& Lavikka (2013) on tarkasteltu Aliisan toimintatapoja johtajuuden näkökulmasta. Aliisan ja yrityksen anonymiteetin suojaamiseksi yksityiskohtaiset tunnistetiedot on häivytetty. 